\title{
THE MONARCH OF THE FOREST
}

Charlie W. Abra, Usherville

Some years ago, in the early part of the summer, I was following an old Indian trail through the Maloneck Hills Forest Reserve. The trail was narrow and winding up and down hill.

As I came round a bend, going up hill, a big moose came around another bend coming down hill. He slid to a stop about ten yards from me. He must have been as surprised as I was because he remained, as if frozen, with his feet pushed down hill in front of him. He did not look unfriendly-just very surprised. I stood and looked at him for probably fifteen seconds, then I began to think it was a little too close to be to a live moose - so I started to back away from him. When I was about twenty yards away, he suddenly straightened up, and made a hasty get-away to the north and into the timber.

A few years ago, moose had become very scarce in Northern Saskatchewan. It almost seemed as if they were on the way out. They are now protected by a logical and far-seeing conservation measure. They are not plentiful but are definitely making a come-back. The north woods would indeed be desolate without this monarch of the forest.

The moose does not molest the settlers' grain fields or hay. Its food is in the forest and it is abundantthe hazel bush and buck-bush on the

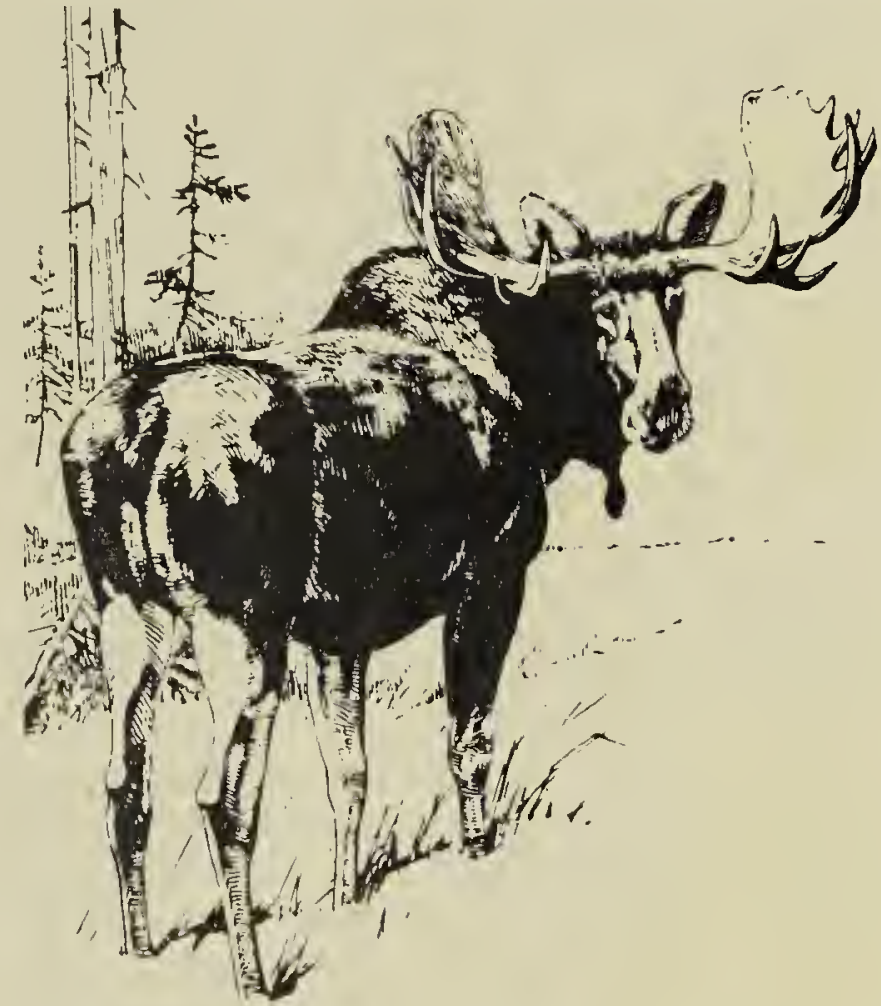

ridges, almost every shrub and plant that grows in the forest is relished by him. If you travel through the bush in the fall of a year when they are plentiful you will see the white blazes on the poplars where they have rubbed the velvet from their horns.

Some winters the moose become infested with wood ticks, especially in late March, but as soon as the lakes open up in the spring they get rid of the ticks. They wade in the water up to their backs and stand there until the irritating insects loosen and fall off.

\section{NATURAL AREA PRESERVES}

Submitted by M. McConnell, Director of Conservation Education, Regina.

"How to preserve an area" is the title of a new bulletin issued by the Nature Conservancy. It is written for the landowner and it discusses the problems he faces in attempting to assure permanent preservation of natural conditions on his property.

The bulletin commences with an analysis of the objectives a person might have in wanting to preserve an area. It goes on to discuss types of preservation, requirements for assuring perpetuation of a nature reserve, custodial agreements, buffer areas, preservation under private ownership, and management policies for natural area preserves.
The Conservancy stresses three essential requirements for assuring preservation of a nature reserve: 1 ) management under a stated policy of preservation, 2) assurance of continuing control by a permanent organization, and 3 ) assurance of continuing maintenance funds from endowment or other sources. It discusses the value of buffer areas and the need for careful planning to assure perpetual protection of a proposed nature reserve.

Copies may be obtained from the Nature Conservancy, 1840 Mintwood Place, N.W.. Washington 9, D.C. 